\title{
Lichen Planus Due to Hirudotherapy
}

\author{
Hirudoterapiye Bağll Liken Planus \\ (1) Munise Daye ${ }^{1}$, (1) Begüm Işık ${ }^{1}$, (1) Fahriye Kılınç² \\ ${ }^{1}$ Necmettin Erbakan University Meram Medical School, Department of Dermatology, Konya,Turkey \\ ${ }^{2}$ Necmettin Erbakan University Meram Medical School, Department of Pathology, Konya, Turkey
}

Cite this article as: Daye M, Işık B, K1lınç F. Lichen Planus Due to Hirudotherapy. Turkiye Parazitol Derg 2021;45(2):149-152.

\begin{abstract}
Lichen planus is a traumatic (koebner positive), chronic, inflammatory and autoimmune disease affecting the oral and genital mucosa, scalp and nails. The Food and Drug Administration approved the use of medical leeches for therapeutic purposes (hirudotherapy) in 2004 to ensure flap nutrition in plastic surgery. A 34-year-old male patient was admitted to our dermatology outpatient clinic with a swollen, itchy and purple-coloured rash on legs and back for a month, and white and reticulated plaques in the mouth. It was learned that a week earlier, eight leeches was applied to both knees and ankles to alleviate knee and leg pain. The patient had no history of drug use. A punch biopsy was taken from the patient with a preliminary diagnosis of lichen planus and lichenoid drug reaction. The histopathological examination showed hyperkeratosis, irregular acanthosis and hypergranulosis. Systemic methylprednisolone, levocetrizine and topical methylprednisolone aceponate were planned for the therapy. To the best of our knowledge, the appearance of lichen planus after hirudotherapy was never reported in literature. Hence, physicians should keep in mind that lichen planus and similar dermatoses could be triggered due to hirudotherapy. The fact that lichen planus appeared a week after hirudotherapy does not necessarily mean that leeches were the cause of this phenomenon. Accordingly, it could be deduced that lichen planus was probably developed as a result of leech therapy.
\end{abstract}

Keywords: Hirudotherapy, leech therapy, lichen planus

Öz

Liken planus oral ve genital mukoza, saçlı deri ve tırnakları ekileyen travma ile tetiklenen (koebner pozitif) kronik, enflamatuvar, otoimmün bir hastalıktır. Tıbbi sülüklerin iyileşme amaçlı kullanımı (hirudoterapi) plastik cerrahide flep beslenmesini sağlamak için 2004 yılında Gıda ve İlaç İdaresi tarafından onaylanmıştır. Otuz dört yaşında erkek hasta, bir ay boyunca bacaklarda ve sırtında kabarık, kaşıntılı, mor renkli döküntü ve ağızda beyaz ağsı plaklarla dermatoloji polikliniğimize başvurdu. Başka ilaç kullanım öyküsü yoktu. Liken planus ve likenoid ilaç reaksiyonu ön tanısı alan hastadan punch biyopsisi alındı. Histopatolojik incelemede hiperkeratoz düzensiz akantoz ve hipergranüloz görüldü. Tedavi için sistemik metlprednizolon, levosetrizin ve topical metilprednizolon aseponoat planlandı. Bildiğimiz kadarıyla hirudoterapi sonrası liken planus literatürde daha önce bildirilmemiştir. Hirudoterapiye bağlı olarak liken planus ve benzeri dermatozların tetiklenebileceği daima akılda tutulmalıdır. Liken planusun hirudoterapiden bir hafta sonra ortaya çıkması, sülüklerin bu fenomenin mutlak nedeni olduğu anlamına gelmez. Buna göre liken planusun muhtemelen sülük tedavisinin bir sonucu olarak geliştiği söylenebilir.

Anahtar Kelimeler: Hirudoterapi, sülük tedavisi, liken planus

\section{INTRODUCTION}

Lichen planus is a chronic, inflammatory, autoimmune disease that affects the skin, oral and genital mucosa, scalp, and nails $(1,2)$. It usually starts acutely, and is often characterized by erythematous papules and plaques which appear in the forearms, and leg flexor surfaces, and usually is triggered by trauma (1). The use of leeches for therapeutic purposes (hirudotherapy) was approved by the Food and Drug Administration in 2004 to ensure flap nutrition and to salvage detached fingers, nose and ears in plastic surgery. In our country, in 2014, within the scope of the Traditional and Complementary Medicine Practices (T\&CM) regulation, leeches therapy was allowed in cases of degenerative joint diseases, lateral epicondylitis, and venous insufficiency after flap surgery (3).

In recent years, T\&CM applications including hirudotherapy have been increasing (4). The aim of this report is to show that lichen planus could be developed after leech therapy.

\section{CASE REPORT}

A 34-year-old male patient was admitted to our dermatology outpatient clinic having had a swollen,

Received/Geliş Tarihi: 07.07.2020 Accepted/Kabul Tarihi: 09.09.2020

Address for Correspondence/Yazar Adresi: Munise Daye, Necmettin Erbakan University Meram Medical School, Department of Dermatology, Konya,Turkey

Phone/Tel: +90 5326062630 E-mail/E-Posta: dr_munise@yahoo.com ORCID ID: orcid.org/0000-0002-6614-1821 
itchy, purple-colored rash on the legs as well as white, reticulated rashes in the mouth for the last 4 weeks.

The patient reported that a week earlier eight leeches were applied to both knees and ankles to alleviate his symptoms for knee and leg pain. During the following 4 weeks a rash appeared in his abdomen, arms, and genital area. He had no history of drug use. The examination of the patient revealed white plaques in the oral mucosa with reticular branching, as well as in the perimalleolar area and knees, which were the sites of leech application, but also in areas where leeches were not applied such as the lower extremities. Purple papules were observed around the penis, sacrum, forearm, and anterior abdominal wall (Figure 1-3).

A punch biopsy was taken from the patient with a preliminary diagnosis of lichen planus and lichenoid drug reaction. Histopathological examination revealed hyperkeratosis, irregular acanthosis, hypergranulosis, lymphocyte-dense band-like cell infiltration in the upper dermis, and infrequent dyskeratotic cells in the periphery of the epidermis (Figure 4, 5). The clinical and histopathologic diagnosis was this of lichen planus. We assume that that lichen planus developed as a results of hirudotherapy. The patient was treated with methylprednisolone $60 \mathrm{mg} /$ day and levocetrizine once a week with a gradually reduced dose, as well as with topical methylprednisolone aceponate once a day. After two weeks, the patient's complaints subsided (Figure 6, 7). The patient is still being followed up at our clinic. Informed consent was obtained from the patient for the publication of this case report and images.

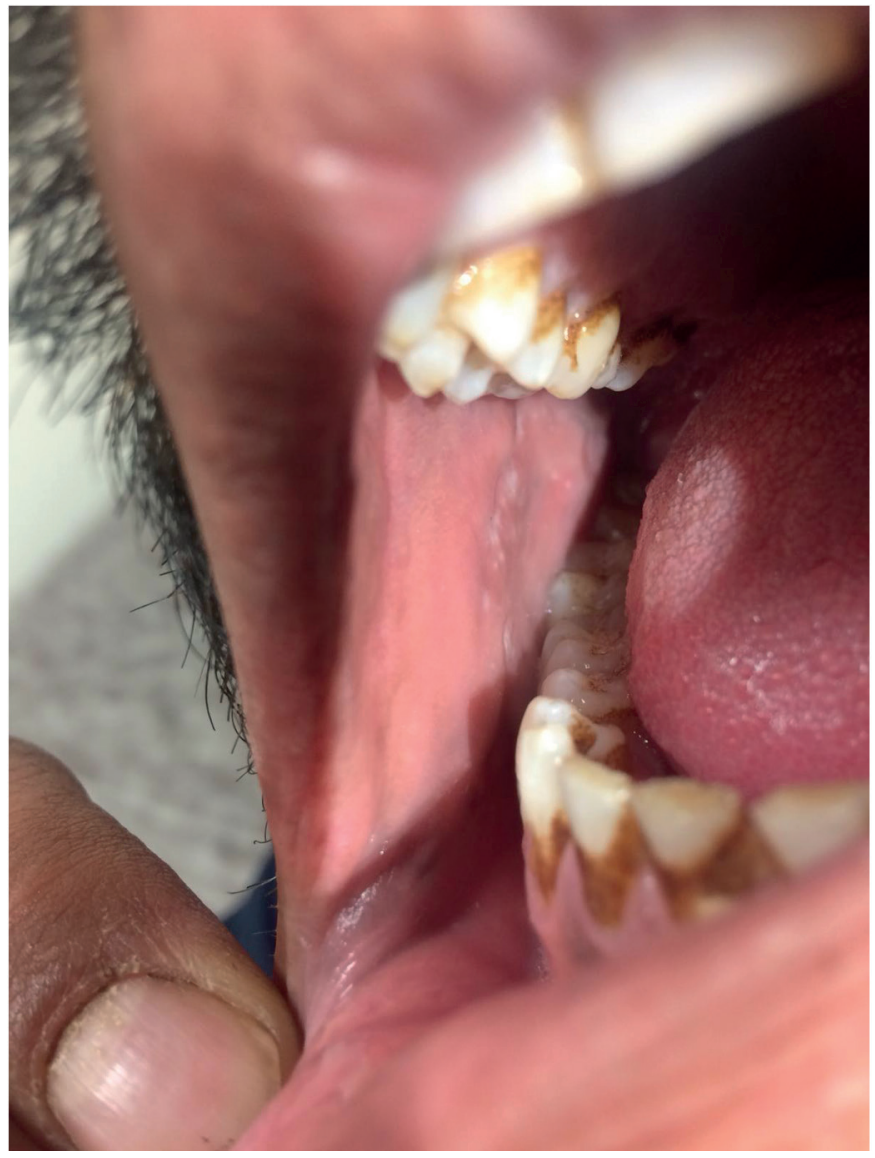

Figure 1. White plaques showing reticular branching were on the buccal mucosa

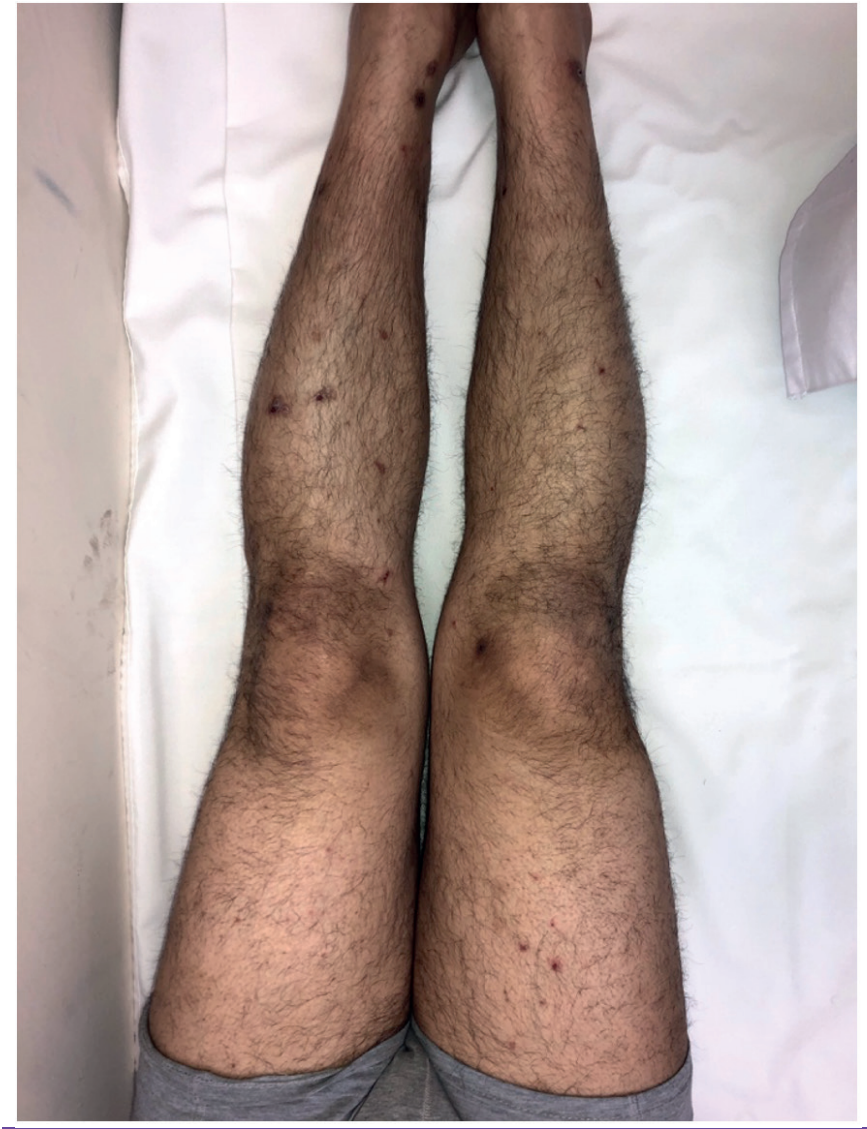

Figure 2. Purple, hypertrophic plaques in the lower limbs and diffuse lichen papules on the leg

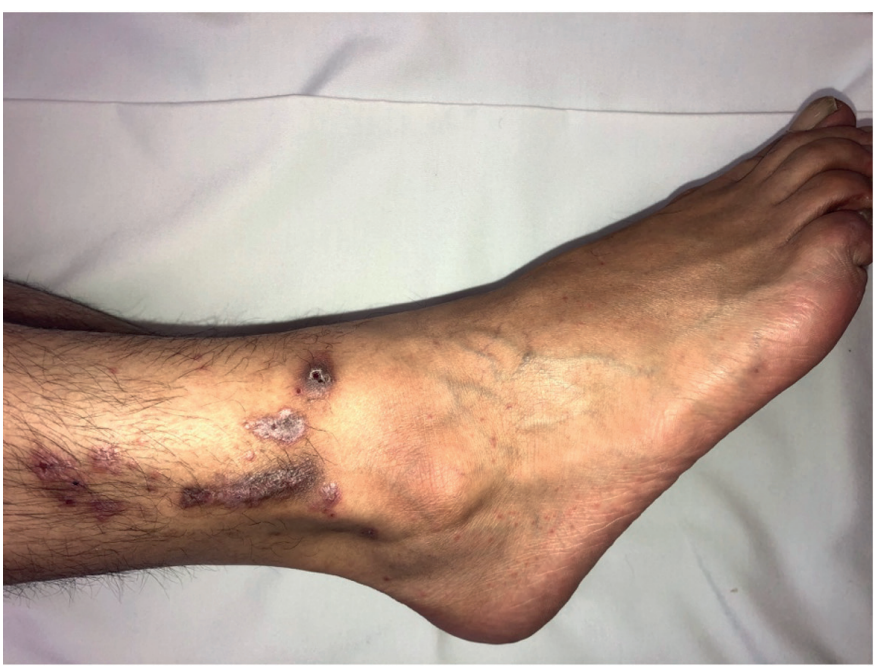

Figure 3. Purple, hypertrophic plaque on the right perimalleolar region

\section{DISCUSSION}

Lichen planus is often found in women, but it also affects middleaged adult males such as in our case. In the dermatological examination the flexor faces of the wrists and forearms, the dorsal side of the wrists, the front of the legs, the neck and sacral areas have polygonal shaped, purple, flat, itchy, and shiny papules. On the surface of the papules, fine white mesh lines, called Wickham lines, could be seen. Oral lichen planus has a white, lace, reticular appearance on the buccal mucosa $(1,2)$. 


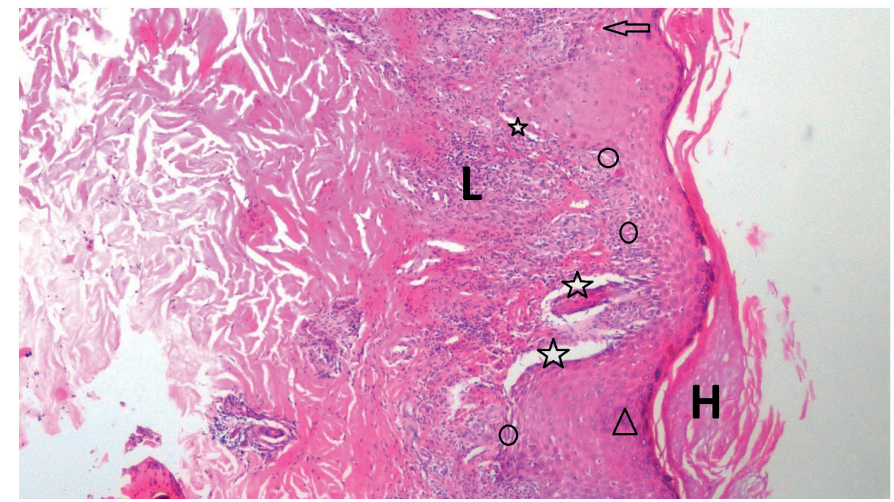

Figure 4. Hyperkeratosis (H), increased granular layer (triangle), lymphocytic infiltration (L), dyskeratotic cell (arrow) are seen in the histopathology (hematoxylin/eosin, image 4, 40x; image 5, 40x)

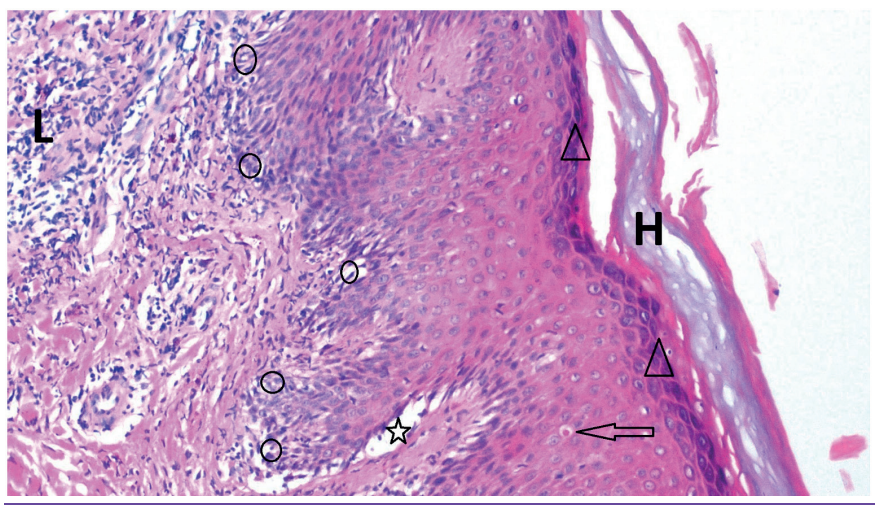

Figure 5. Hyperkeratosis (H), increased granular layer (triangle), lymphocytic infiltration (L), dyskeratotic cell (arrow) are seen in the histopathology (hematoxylin/eosin, image 4, 40x; image 5, 40x)

Leeches are ectoparasites and feed by sucking blood. Hirudo medicinalis and Hirudo verbana are used for treatment. There are more than 20 active ingredients in the saliva of leeches, having analgesic, anti-inflammatory, anticoagulant, and antimicrobial properties $(5,6)$. Bioactive molecules such as eglins and bdellins in saliva can contribute to the treatment of psoriasis by decreasing erythema and vasodilation by displaying anti-inflammatory activity, and fibrinase and collagenase can reduce scar tissue, as such positive effects have been reported in the treatment of hypertrophic scar and keloid. Many substances in leech saliva have been observed to reduce itching by accelerating microcirculation, and reducing cells such as lymphocytes and inflammatory intermediates $(4,7)$.

The etiopathogenesis of lichen planus is not yet fully understood. It has been found to be associated with triggers such as viral infections, autoimmune diseases, drugs, vaccines, and dental materials. It is thought that cell surface antigens change due to the damage in basal keratinocytes with triggers, causing the formation of lichen planus $(1,2)$. The presence of CD8 + T lymphocytes in older lesions supports this autoimmune damage. This circulating T-cell migration plays an important role in the onset of the immune response (2). Lichen planus is a disease with an isomorphic response (koebner positive) that defines the emergence of a new lesion within two days to two years following traumatic stimulation of the skin (1). In our case, it was thought

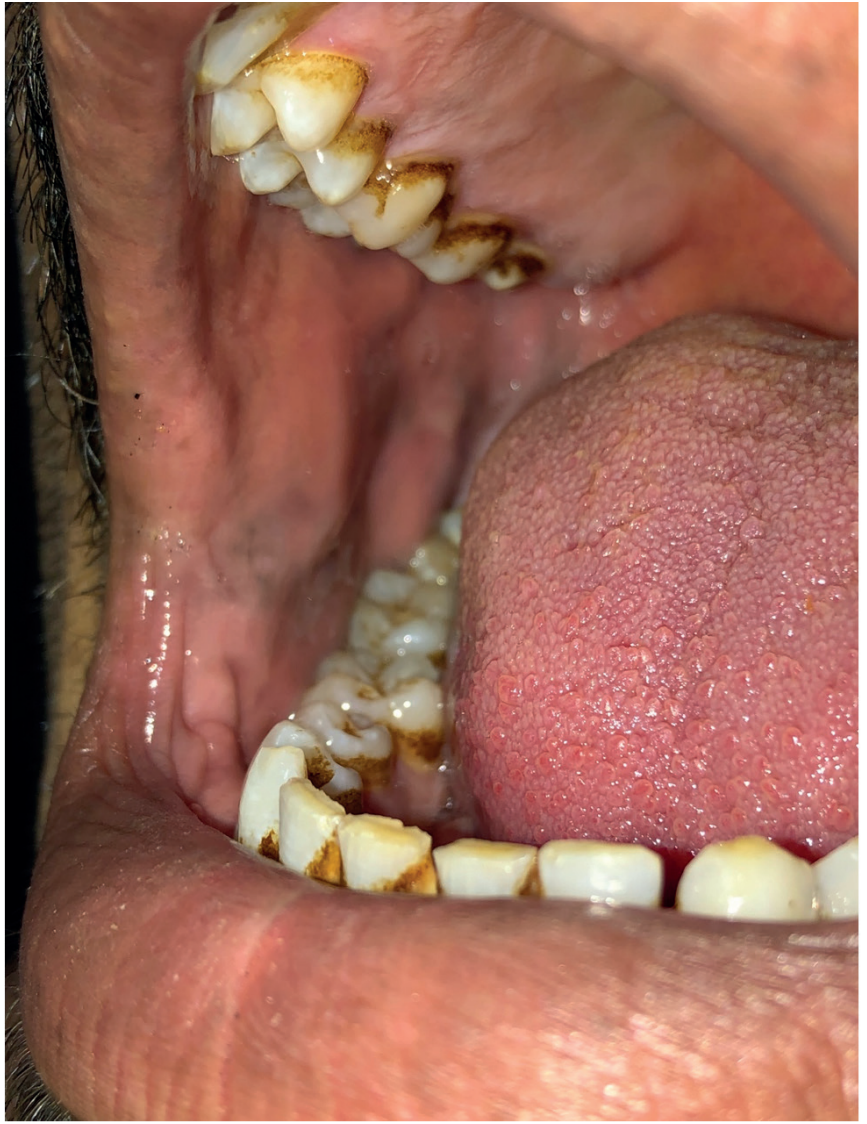

Figure 6. Regression in white plaques on the buccal mucosa

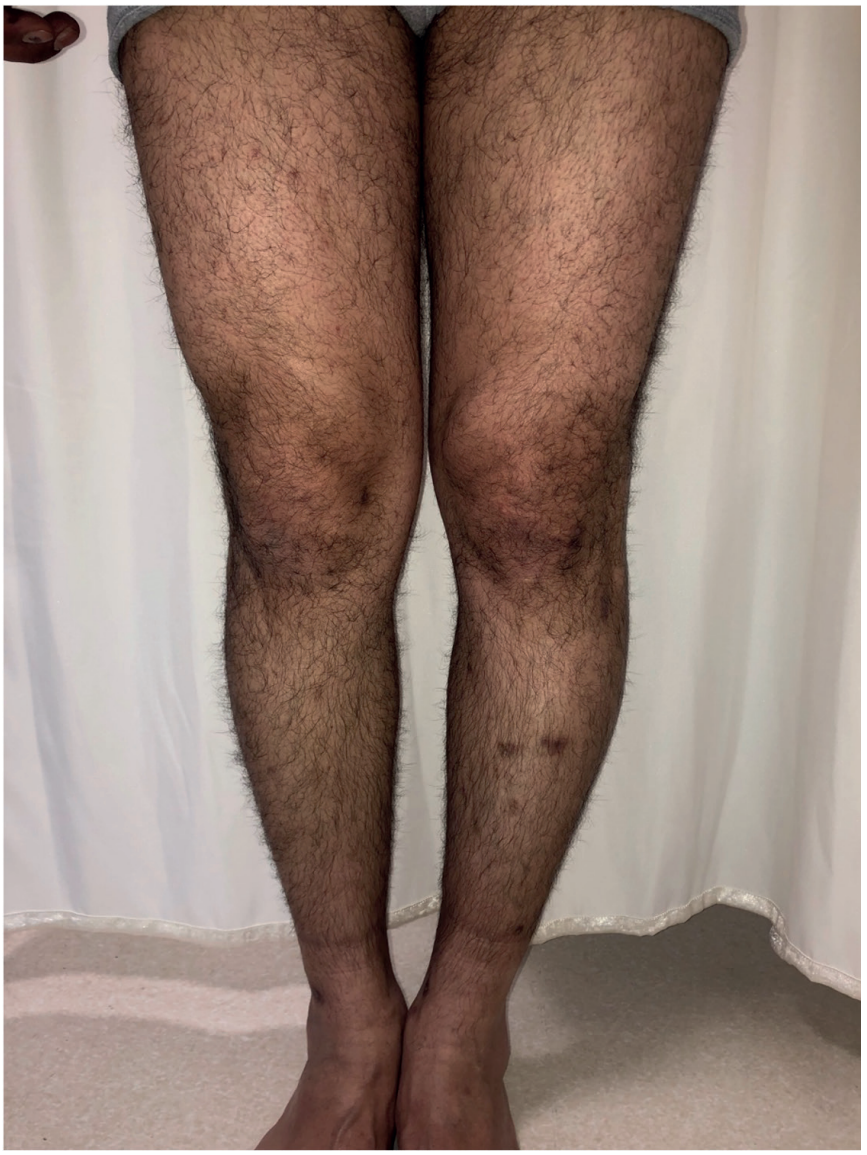

Figure 7. Post-inflammatory macules on the lower limbs 
that the lichen planus started with the reaction developed against one or more components of leech saliva. We assume that the Koebner phenomenon, which was formed due to the bite of the leech, also increased the severity of the disease.

It was reported that pyoderma gangrenosum has developed in the perimalleolar region after hirudotherapy in a case with ulcerative colitis, and this situation was explained by the phenomenon of pathergy (8). A case of cutaneous pseudolymphoma compatible with the applied place was detected after a leech was applied to the neck area. It has been suggested that pseudolymphoma occurs as a result of trauma secondary to the leech bite (9). Although lichen planus and lichenoid drug eruption are clinically similar, in lichenoid drug eruption, the lesions are polymorphic, devoid of Wickham striae and show marked desquamation. The symptoms occur weeks or months after taking the drug and the lesions regress when the drug is stopped. Although the age, gender, and hirudotherapy was compatible with lichenoid eruption in our case, the presence of Wickham striae, the lesions progressing with monomorphic papules, and the fact that the lesions did not regress despite the end of hirudotherapy, caused us to move away from lichenoid drug eruption. In our case, the histopathological findings were similar to idiopathic lichen planus.

In the treatment of lichen planus, emollients, glucocorticoids, calcipotriol, calcineurin inhibitors (pimecrolimus, tacrolimus) are used topically. Systemic steroids, acitretin, metronidazole, cyclosporin, mycophenolate mofetil, antimalarials, sulfasalazine, griseofulvin, hydroxychloroquine, and methotrexate, phototherapy can also be used (2). In our case, dermatological improvement was achieved within two weeks with a systemic and topical steroid treatment.

\section{CONCLUSION}

In our study, lichen planus possible due to hirudotherapy was the first case reported in the literature. Indications and contraindications of hirudotherapy, which is being used officially in hospitals, should be taken into consideration. Along with the increasing use of hirudotherapy, reports of side effects are likely to increase and physicians should be aware.

\section{* Ethics}

Informed Consent: Informed consent was obtained from the patient for the publication of this case report and images.

Peer-review: Internally peer-reviewed.

\section{** Authorship Contributions}

Surgical and Medical Practices: M.D., B.I., F.K., Concept: M.D., B.I., F.K., Design: M.D., B.I., F.K., Data Collection or Processing: M.D., B.I., F.K., Analysis or Interpretation: M.D., B.I., F.K., Literature Search: M.D., B.I., F.K., Writing: M.D., B.I., F.K.

Conflict of Interest: No conflict of interest was declared by the authors.

Financial Disclosure: The authors declared that this study received no financial support.

\section{REFERENCES}

1. Sagi L, Trau H. The Koebner phenomenon. Clin Dermatol 2011; 29: $231-$ 6.

2. Bolognia J, Jorizzo J, Rapini R. Lichen Planus and Lichenoid Dermatoses. Dermatology, 2nd ed., Elsevier Inc 2008: p. 167-70.

3. Ayhan H, Mollahaliloğlu S. Tibbi sülük tedavisi: Hirudoterapi. Ankara Medical Journal 2018; 18: 141-8.

4. Gödekmerdan A, Arusan S, Bayar B, Sağlam N. Tibbi sülükler ve hirudoterapi [Medicinal leeches and hirudotherapy]. Turkiye Parazitol Derg 2011; 35: 234-9.

5. Singh AP. Medicinal leech therapy (hirudotherapy): a brief overview. Complement Ther Clin Pract 2010; 16: 213-5.

6. Sig AK, Guney M, Uskudar Guclu A, Ozmen E. Medicinal leech therapy-an overall perspective. Integr Med Res 2017; 6: 337-43.

7. Iqbal A, Shah A, Quraishi HA, Rather SA, Raheem A. Effect of leech therapy in the management of psoriasis. J Res Tradit Med 2018; 4: 16-20.

8. Sadeghi A, Navabakhsh B, Izadi Vahedi N. Leech Induced Pyoderma Gangrenosum in an Ulcerative Colitis Patient: A Case Report. Middle East J Dig Dis 2016; 8: 63-6.

9. Temiz SA, Özer İ, Ataseven A, Dursun R, Findık S. Cutaneous Pseudolymphoma Due to Hirudotherapy. Turkiye Parazitol Derg 2019; 43: 50-2. 